\title{
Hyaluronsyrens betydning i nyfødtperioden
}

\section{Degradering av hyaluronsyre forekommer i situasjoner som asfyksi og infeksjon hos nyfødte. Resuscitering med $100 \%$ oksygen øker slik degra- dering i lungene hos spedgris.}

Hyaluronsyre, også kalt hyaluronan, er en bestanddel av ekstracellulær matriks, men også en markør for vevsskade og inflammasjon som kan frigjøres til blodbanen. Mens den høymolekylære formen er antiinflammatorisk og viktig for strukturell integritet, er den lavmolekylære formen proinflammatorisk. Hyaluronsyre utøver sine effekter gjennom flere reseptorer, blant annet Toll-liknende reseptor 4 (TLR4).

I mitt doktorgradsarbeid undersøkte jeg effekt av resuscitering på hyaluronsyredegradering i lungene hos nyfødte griser og fant $ø \mathrm{kt}$ degradering ved resuscitering med 100\% oksygen sammenliknet med bruk av romluft. Antioksidanten $\mathrm{N}$-acetylcystein beskyttet mot slik degradering. Jeg studerte også reseptorer for hyaluronsyre i navlesnorsblod. Lipo- polysakkarid ble brukt for å etterlikne en situasjon med nyfødtsepsis. Tilstedeværelse av hyaluronsyre medførte lavere ekspresjon av TLR4 på overflaten av monocytter. I en annen studie fant vi redusert genekspresjon av TLR4 i navlesnorsblod hos barn som senere utviklet en alvorlig infeksjon med respiratorisk syncytialt virus.

Disse funnene kan gi økt forståelse for hvordan $100 \%$ oksygen kan skade den nyfødtes lunger. Funnene tyder også på at hyaluronsyre og hyaluronsyrereseptorer spiller en viktig rolle for immunforsvaret til den nyfødte.

Helene Caroline Dale Østerholt

helene_dale@hotmail.com

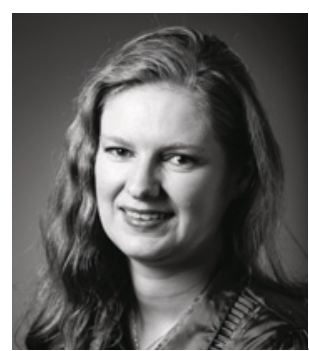

Helene Caroline Dale Østerholt. Foto: Øystein Horgmo

Disputas

Helene Caroline Dale Østerholt disputerte for ph.d.-graden ved Universitetet i Oslo 26.3. 2014 Tittelen på avhandlingen er Hyaluronan in the neonatal period. An experimental and clinical study in asphyxia and infection.

\section{Gammaknivbehandling av hjernesvulster}

Gammaknivbehandling er et viktig alternativ for kirurgisk vanskelig tilgjengelige og stråleresistente intrakraniale svulster. Sulfasalazin øker strålefølsomheten ved gammaknivbehandling for glioblastoma multiforme.

På tross av at gammakniv i mer enn 50 år er blitt benyttet $i$ behandlingen av benigne og maligne intrakraniale lidelser, er det fortsatt mange usikkerhetsmomenter knyttet til effekten.

I mitt doktorgradsarbeid har jeg gjennomgått langtidsresultater ved gammaknivbehandling for sinus cavernosus-meningeom, glioblastomresidiv og hjernemetastaser fra malignt melanom og kolorektal cancer. Gammaknivbehandling har lavere komplikasjonsrate enn kirurgi og konvensjonell strålebehandling for disse indikasjonene, og livskvaliteten er bevart hos pasientene etter gammaknivbehandling for hjernemetastaser.

Til slutt har jeg utviklet en dyremodell for eksperimentell gammaknivbehandling av glioblastom og undersøkt sulfasalazin som et potensielt strålesensitiverende medikament ved glioblastombehandling av rotter. Den eksperimentelle delen viser at sulfasalazin øker stråleeffekten både i gliomcellelinjer in vitro og hos nakne rotter med humane glioblastoma multiforme-xenotransplantater.

Funnene har betydning for valg av behandling ved ovennevnte tilstander og som basis for pasientinformasjon før behandling. De eksperimentelle funnene har munnet ut i søknad om klinisk utprøvning av sulfasalazin som strålesensitiviserende medikament med mål om å bedre fremtidig behandling av glioblastoma multiforme.

\section{Bente Sandvei Skeie}

bente.sandvei.skeie@helse-bergen.no

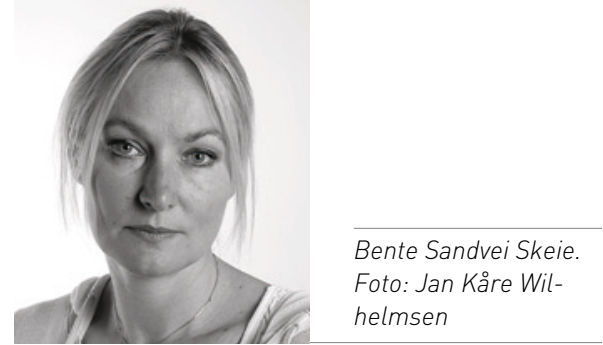

Disputas

Bente Sandvei Skeie disputerte for ph.d.graden ved Universitetet i Bergen 20.6.2014. Tittelen på avhandlingen er Gamma knife surgery for intracranial tumours - clinical and experimental studies. 